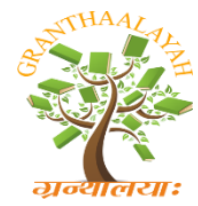

INTERNATIONAL JOURNAL OF RESEARCH GRANTHAALAYAH A knowledge Repository

Management

\title{
A STUDY ON CONSUMERS PREFERENCE TOWARDS MALTED FOOD IN KANYAKUMARI
}

\author{
Dr.P.Antony Raj $^{* 1}$, S.Shiny ${ }^{2}$ \\ *1 Associate Professor of Commerce, St.Jude's College, Thoothoor, India \\ ${ }^{2}$ Assistant Professor of Commerce, St.Jude's College, Thoothoor, India
}

DOI: https://doi.org/10.29121/granthaalayah.v5.i4(SE).2017.1949

\begin{abstract}
Over the last decade the health consciousness of consumers has become an important factor driving the agri-food market .Healthier food products have entered the global markets with force in the past years and rapidly gained market share. Various studies have concluded that better understanding of consumer perception of healthy food its determinants are key success factors for market orientation and development and for successfully negotiating market opportunities .The basic purpose of this research paper is to identify the influence of various factors on the buying decision of consume and also attempts to determine the awareness and perception of the consumers.
\end{abstract}

Keywords: Consumer; Preference; Malted Food.

Cite This Article: Dr.P.Antony Raj, and S.Shiny. (2017). "A STUDY ON CONSUMERS PREFERENCE TOWARDS MALTED FOOD IN KANYAKUMARI." International Journal of Research - Granthaalayah, 5(4)SE, 52-62. 10.29121/granthaalayah.v5.i4(SE).2017.1949.

\section{Introduction}

Today parents are very health consciousness for their children. Women Empowerment forces the change in eating behavior of women and them too conscious about their health. Now old people are also using the energy drink or malt food drink to boost their energy. Milk is the important liquid drink consumed by consumer does not drink milk alone, but with combination for healthy drink. Over nearly the past 30 years, US children and adolescents have dramatically increased their consumption of sugar - sweetened beverages including soda, fruit drinks and punches and sports drinks. In India first health drink introduced is Cadbury Bournvita. It is previously called Bourn-vita, is the name of a brand of malted and chocolate malt drink mixes sold in Europe and North America, as well as India, Nepal, Nigeria, Ghana, South Africa, Benin and Togo and manufactured by Cadbury. Bournvita was discontinued in the UK market in 2008. The drink was named by Cadbury which was derived from Bournvita, the model village which is the site of the 
Cadbury factory (Bournvita). It was first sold in 1949. After that other brands introduced in India ie, Complan, Boost, Horlicks, Nestle milo.

Malt Based Foods or Malt Food means the product obtained by mixing malt (wort or flour or malt extract) of any kind obtained by controlled germination of seeds (cereals and / or grain legumes). involving mainly steeping germination and kiln drying processes with other cereal and legume flour with or without whole milk or milk powder, flavouring agents, spices, emulsifying agents, egg, egg powder, protein isolates, protein hydrolysates, edible common salt, liquid glucose, sodium or potassium bicarbonate minerals, amino acids and vitamins. It may contain added sugar and / or cocoa powder and processed in such a manner to secure partial or complete hydrolysis of starchy. Material in the form of powder or granules or flakes by drying or by dry mixing of the ingredients. The grains, legumes and their products used in preparation of malt shall be sound, uninfected and free from insect fragments, rat excreta, fungal infested grains or any other type of insect or fungal damage.

In tune with the overall trend of Indian economy and consumption pattern the fast moving consumer Goods (FMCG) sector one of the largest employers and a prominent user of agriculture output also remains vibrant processed and packaged malted food industry an important of FMCG sector has become the field of the study due to its intriguing but interesting trend.

\section{Statement of the Problem}

Food processing, the largest segment in FMCG is lagging behind in India in comparison to developed countries. Positively speaking it exhibits the growth potentials for the investors in this sector in India sensing the under explored food market in India, domestic and multinational companies of late have been targeting this sector to find a pertinent source of income for them in the long run. Rapid globalization supported by explosive industrial and infrastructural growth, expansion in the income of households along with the real increase in spending power, growing urbanization, availability of multiple varieties of products in several categories, charging role of women, busy lifestyles and evolving prefertial options portray the find market in India as promising multifaceted competitive and aggressive one.

The present study focuses on one of the core and critical components of processed and packaged foods namely malted food. This segment has now come under the close security and attention of the state and central governments, owing to its pivotal role in enhancing the general health of otherwise malnourished Indian population infact the government is contemplating a series of measures to improve the performance and production of this segment so that the people from lower income segment of population can have continuous access to malted food. Moreover, the government authorities and the officials who formulate policies, also keenly interested in knowing consumer preference in relation to malted food. 


\section{Review of Literature}

Bauorakis (2007) ${ }^{1}$ conducted a study on brand preference in selected European Union countries through investigation on various product characteristics such as price, quality/taste, image/reputation, advertising, packaging and colour of Greek and Dutch Juice markets. Specific product attributes found to be important determinant of brand preference and multivariate regression analysis were used to describe consumer preferences for the examined brands.

Rajagopal (2009) $)^{2}$ in his study conducted to know conational drivers influencing brand preference among consumers during shopping seasons for familiar and non-familiar brands, taking into account 39 variables, found that the higher brand relevance and trust could construct durable close association between consumers and brand. Brands had higher values when they were from company having a consumer friendly image and ensuring long standing performance in the market. Differentiation adopted in selling strategies made consumers to recognize brands effectively. Consumer satisfaction could play a greater role in building higher brand trust. Origin of the brands, one of the brands' attributes was found to be the significant influencer of durable consumer association with brands.

Brands which were consumer centric and ensuring higher satisfaction could earn higher satisfaction and acquire the status of loyal brands. Effective advertising and communication could create awareness among consumers and build everlasting association with the brands.

Joel Espejel et al (2009) $)^{3}$ through their study on the influence of consumer involvement construed that the quality attributes had influenced differently on perceived risk, trust, satisfaction and loyalty between high involvement consumers and low involvement consumers. It was also found out that the intrinsic and extrinsic perceived quality on the consumers' loyalty level is higher for highly involved consumers than their counterpart.

\section{Objectives of the Study}

The present study has formulated objectives with the aim to accomplish the main purpose of the study.

1) To present demographic profile of consumers in Kanyakumari district and study the spending and consumption pattern of consumers towards malted food.

2) To identify the problems faced by the consumers in the consumption of malted food.

3) To know the level of brand preferences for the most preferred brand.

4) To examine the factors influencing buying decision among consumers for malted food in kanyakumari district.

5) To know the general perception of consumers on malted food.

${ }^{1}$ George Baourakis, George Baltas, meline Izmiryan and Nikos Kalogeras, Brand preference: A comparative consumer study in Selected EU countries, Operation Research - an international Journal Vol 7, No1. (2007) pp 105-120.

${ }^{2}$ Rajagopal, Conational Drivers Influencing Brand preference among consumers, working paper 2009- 02-Market, EGADE, April 2009.

${ }^{3}$ Joel Espejel, Carmina, Fandos and Carlos Flavian, The influence of consumer involvement on quality signals perception. An empirical investigation in the food sector, British Food Journal Vol. III No. 11, 2009. 
6) To study the satisfaction level of consumers towards preferred brand of malted

\section{Scope of the Study}

This study aims at providing an in-depth analysis and understanding into the consumer preference towards malted food in kanyakumari district along with their brand preferential aspects. Even though, malted food items include a large number of items belonging to malted food drinks category and malted food eatable category, this study is confined to malted food drinks only. Moreover, among the various malted food drinks, the five malted food drinks, which were identified as widely used through a pilot study, were taken into account for the study. The pilot study was conducted in kanyakumari District with the help of interview schedule. The five malted food drinks are Horlicks, Bournvita, Complan, Boost and pediasure.

\section{Methodology}

The methodology includes the research design, period of the study, process of data collection, sampling design and statistical tools for analysis.

\section{Research Design}

The study requires the data to be collected from two different sources i.e, the primary source and the secondary source. Primary data were collected through a well-structured interview schedule. The secondary data were collected from books, journals, newspaper and various reports related to malted food and websites.

\section{Period of the study}

The primary data has been collected for a period of one year from April 2014 to March 2015.

\section{Process of Data Collection}

A comprehensive interview schedule was prepared by the researcher on the basic of objectives, in order to elicit relevant information from the sample respondents who are consuming malted food. The interview schedule was finalized after having made a pretest through a pilot study. The collection of data was done by using personal interview method in which pre coded schedules have been used to obtain relevant data from the sample respondents.

\section{Pilot Study}

Before the commencement of the research work a pilot study was made to have a better knowledge. For the pilot study, an interview schedule was constructed. The pilot study was conducted with fifty respondents of the study area. After the pilot study, the interview schedule was modified with necessary corrections as per the suggestions given by the respondents.

\section{Sampling Design}

The Kanyakumari district has been taken for the present study. There are four taluk in kanyakumari district namely, Agastheeswaram, Thovalai, Vilavancode, Kalculam. In this study proportionate stratified random sampling technique has been followed. The size of sample was fixed s 600 households, raking into account the time, cost and administrative considerations, and 
the size of sample fixed in the similar previous studies. This sample size was proportionately stratified (divided) among all the nine blocks in kanyakumari district.

\section{Frame work Analysis}

The collected data had been processed with the help of appropriate statistical tools. The statistical tools were selected on the basic of the objectives of the study and also the nature of data included in the analysis. The details of statistical tools and its relevance of application is summarized below.

1) Percentage analysis was used to measure the demographic profile and

2) Factor Analysis is employed to find out the factors influence the consumers on the buying decision of malted food.

\section{Analysis and Interpretation}

\section{Factors influence the consumers on the buying decision of Malted Food Drinks}

Factor analysis helps to reduce the innumerable variables into limited number of latent factors having inter-correlation within themselves. Hence factor analysis is attempted to reduce the numerous variables into limited number of factors. In order to apply factor analysis, the basic assumption to be fulfilled is the factorability of the correlation matrix. KMO measures of sampling adequacy and the Bartlett's test of sphericity determine the factorability of the correlation matrix. The results of the calculation are presented below.

Table 1: KMO and Bartlett's Test

\begin{tabular}{|l|l|l|}
\hline \multicolumn{2}{|l|}{ Kaiser-Meyer-Olkin measure of Sampling Adequacy } & 0.832 \\
\hline $\begin{array}{l}\text { Bartlett's Test of } \\
\text { Sphericity }\end{array}$ & Chi-Square & 1724.027 \\
\cline { 2 - 3 } & Degrees of freedom & 153 \\
\cline { 2 - 3 } & Significance & 0.000 \\
\hline
\end{tabular}

Source: Computed Data

High value of Kaiser - Meyer - Olkin (KMO) test of sample adequacy (0.832) indicates the correlation between the pairs of variables explained by other variables and thus factor analysis is considered to be appropriate in this model.

The Bartlett's test of sphericity chi-square indicates the population correlation matrix. It is an intensity matrix. The test of statistics for sphericity is based on $\mathrm{X}^{2}$ test, which is significant. The value is 1724.027 .

Findings of the KMO and Bartlett's test reveals that the factor analysis can be rightly employed in this context as evidenced through a higher KMO Measure (0.832) and a significant Bartlett's test result. Hence factor analysis is attempted. Analysis of factors influence the consumers on the buying decision of malted food drinks is made through rotated factor matrix which reveals that there are five major factors influence the consumers on the buying decision of malted food drinks. The findings of the rotated factor analysis on the factors influence the consumers on the buying decision of malted food drinks are presented in Table. 
Table 2: Rotated Factor Matrix for factors influence consumers on the buying decision of malted food drinks

\begin{tabular}{|c|c|c|c|c|c|c|}
\hline Factors & F1 & F2 & F3 & F4 & F5 & $\mathbf{h}^{2}$ \\
\hline Taste & $\overline{2.724}$ & .115 & 166 & .014 & .550 & .404 \\
\hline Buying by friends/neighbours & .718 & .055 & .280 & .028 & .065 & .374 \\
\hline Brand image/company's image & .570 & .152 & .146 & .053 & .042 & .514 \\
\hline Product features/Quality & .528 & .053 & .210 & 291 & .054 & .365 \\
\hline Advertisement & .519 & .343 & .323 & .046 & .062 & .527 \\
\hline Availability in shops frequently buy & .513 & 398 & 141 & 220 & 213 & 475 \\
\hline Price & .172 & .670 & .084 & 097 & 137 & .600 \\
\hline Internet & .154 & .636 & .272 & .104 & .296 & .506 \\
\hline $\begin{array}{l}\text { Word of mouth } \\
\text { colleagues, relatives) }\end{array}$ & -.030 & .608 & 287 & .122 & 088 & 606 \\
\hline Insistence of family members & .409 & .523 & .069 & .245 & .145 & .382 \\
\hline $\begin{array}{l}\text { Packing (Desirable packs) and label } \\
\text { information }\end{array}$ & 281 & .092 & .609 & 416 & 033 & 443 \\
\hline $\begin{array}{l}\text { Sales promotions (free gifts/price } \\
\text { off) }\end{array}$ & 149 & 281 & .608 & 252 & 268 & 633 \\
\hline Celebrity & .176 & .273 & .600 & .120 & .085 & .601 \\
\hline Buying by friends/neighbours & 152 & 260 & .587 & 200 & .120 & 486 \\
\hline Health reasons & .094 & 151 & .050 & .682 & 086 & .318 \\
\hline Departmental stores/Super markets & .097 & .007 & .123 & .583 & .004 & .466 \\
\hline Prescribed by Doctors/Nutritionists & 083 & .308 & 184 & .273 & .826 & 664 \\
\hline Habit & .008 & .002 & 240 & 192 & .755 & .868 \\
\hline
\end{tabular}

Extraction Method : Principal Component Analysis

Rotation Method : Varimax with Kaiser Normalization

Source : Primary Data

The above table exhibits the rotated factor loading for the eighteen statements (variables) of factors influence the consumers on the buying decision of malted food drinks. It is clear from table that all the eighteen statements have been extracted into five factors.

Table 3: Factors influence the consumers on the buying decision of Malted Food Drinks - Factor Wise Analysis

\begin{tabular}{|l|l|l|l|l|}
\hline Sl. No & Factors & $\begin{array}{l}\text { Eigen } \\
\text { Value }\end{array}$ & $\begin{array}{l}\text { Percentage } \\
\text { of } \\
\text { Variance }\end{array}$ & $\begin{array}{l}\text { Cumulative } \\
\text { Percentage of } \\
\text { Variance }\end{array}$ \\
\hline 1. & Brand image and Quality & 2.270 & 13.312 & 13.312 \\
\hline 2. & $\begin{array}{l}\text { Price and influence of family } \\
\text { members }\end{array}$ & 2.079 & 12.193 & 25.505 \\
\hline 3. & Packing and celebrity & 1.868 & 10.955 & 36.460 \\
\hline 4. & Health factor & 1.430 & 8.386 & 44.846 \\
\hline 5. & Doctors/Nutritionists & 1.332 & 7.812 & 52.658 \\
\hline
\end{tabular}


Source: Computed Data

It is observed from table that five factors were extracted out of eighteen variables. These factors accounts for 52.658 percentage variance in the data. Eigen value for the first factor is 2.270 which indicates that the factor contains very high information than other factors.

\section{Factor I (F1) - Brand Image and Quality Factor}

Variables such as, 'Taste' (0.724), 'Buying by friends/neighbours' (0.718), 'Brand image/company's image' (0.570), 'Product features/Quality' (0.528) 'Advertisement' (0.519) and 'Availability in shops frequently buy' $(0.513)$ had the highest significant positive loading and hence were included in the first factor. These variables were directly associated with the brand image and quality. Hence, Factor I, was named as "Brand Image and Quality Factor".

Factor II (F2) - Price and Influence of family members Factor

In the second factor (F2) variables such as 'Price' (0.670), 'Internet' (0.636), 'Word of mouth (Friends, colleagues, relatives)' (0.608), and 'Insistence of family members' $(0.523)$ were found to have the highest significant positive loading and hence they were grouped and included in Factor 2. Variables included in the second factor were closely associated with the price and influence of family members factor. So, the second factor was named as the 'Price and Influence of family members' factor.

\section{Factor III (F3) - Packing and Celebrity Factor}

Variables such as, 'Packing (Desirable packs) and label information' (0.609), 'Sales promotions (free gifts/price off)' (0.608), 'Celebrity' (0.600) and 'Buying by friends/neighbours' $(0.587)$ were found to have the highest significant positive loading and hence they were grouped and included in Factor 3. Hence, this factor III (F3) is called was named as the 'Packing and Celebrity' factor.

\section{Factor IV (F4) - Health Factor}

'Health reasons' (0.682) and 'Departmental stores/Super markets' $(0.583)$ were the variables which were found to possess the highest significant positive loading and they had been included in the Factor IV(F4). These variables were related to health. Hence, the Factor IV (F4) had been named as the 'Health' factor.

\section{Factor V (F5) - Doctors/Nutritionists Prescriptions Factor}

'Prescribed by Doctors/Nutritionists' $(0.826)$ and 'Habit' $(0.755)$ were the variables which were found to possess the highest significant positive loading and they had been included in the Factor $\mathrm{V}(\mathrm{F} 5)$. These variables were related to doctors/nutritionists prescriptions. Hence, the Factor IV (F4) had been named as the 'Doctors/Nutritionists Prescriptions' factor.

\section{Product Features influence the consumers on the buying decision of Malted Food Drinks} Factor analysis helps to reduce the innumerable variables into limited number of latent factors having inter-correlation within themselves. Hence factor analysis is attempted to reduce the numerous variables into limited number of factors. In order to apply factor analysis, the basic assumption to be fulfilled is the factorability of the correlation matrix. KMO measures of 
sampling adequacy and the Bartlett's test of sphericity determine the factorability of the correlation matrix. The results of the calculation are presented below.

Table 4: KMO and Bartlett's Test

\begin{tabular}{|l|l|l|}
\hline Kaiser-Meyer-Olkin measure of Sampling Adequacy & 0.813 \\
\hline Bartlett's Test of & Chi-Square & 1444.732 \\
\cline { 2 - 3 } Sphericity & Degrees of freedom & 66 \\
\cline { 2 - 3 } & Significance & 0.000 \\
\hline
\end{tabular}

Source: Computed Data

High value of Kaiser - Meyer - Olkin (KMO) test of sample adequacy (0.813) indicates the correlation between the pairs of variables explained by other variables and thus factor analysis is considered to be appropriate in this model.

The Bartlett's test of sphericity chi-square indicates the population correlation matrix. It is an intensity matrix. The test of statistics for sphericity is based on $\mathrm{X}^{2}$ test, which is significant. The value is 1444.732 .

Findings of the KMO and Bartlett's test reveals that the factor analysis can be rightly employed in this context as evidenced through a higher KMO Measure (0.813) and a significant Bartlett's test result. Hence factor analysis is attempted. Analysis of product features influence the consumers on the buying decision of malted food drinks are made through rotated factor matrix which reveals that there are five major factors influence the consumers on the buying decision of malted food drinks. The findings of the rotated factor analysis on the product features influence the consumers on the buying decision of malted food drinks are presented in Table.

Table 5: Rotated Factor Matrix for product features influence consumers on the buying decision of malted food drinks

\begin{tabular}{|l|l|l|l|l|l|}
\hline Factors & F1 & F2 & F3 & F4 & $\mathbf{h}^{\mathbf{2}}$ \\
\cline { 1 - 2 } $\begin{array}{l}\text { Extraction from nutritious grains and } \\
\text { nuts }\end{array}$ & $\mathbf{. 7 4 9}$ & .133 & .033 & .054 & .534 \\
\cline { 2 - 5 } & $\mathbf{. 6 5 1}$ & .177 & .207 & .275 & .557 \\
\hline Digestive and absorbing elements & $\mathbf{. 5 7 7}$ & .228 & .181 & .087 & .358 \\
\hline Fragrance or Aroma & $\mathbf{. 5 3 1}$ & .061 & .246 & .065 & .633 \\
\hline Ingredients & .048 & $\mathbf{. 6 8 5}$ & .025 & .248 & .826 \\
\hline Taste & .080 & $\mathbf{. 6 7 5}$ & .287 & .111 & .557 \\
\hline Freshness & .299 & $\mathbf{. 6 5 4}$ & .323 & .106 & .350 \\
\hline $\begin{array}{l}\text { Shelf life (Useable form still the last } \\
\text { spoon) }\end{array}$ & .378 & $\mathbf{. 6 3 6}$ & .026 & .155 & .637 \\
\hline $\begin{array}{l}\text { Nutrients content (Minerals and } \\
\text { Vitamins) }\end{array}$ & .173 & .104 & $\mathbf{. 7 6 8}$ & .076 & .582 \\
\hline Low/Nil fat or cholesterol & .233 & .157 & $\mathbf{. 7 4 4}$ & .043 & .577 \\
\hline Natural one & .024 & .218 & .245 & $\mathbf{. 8 8 1}$ & .723 \\
\hline Minimum or no preservatives/additives & .136 & .276 & .082 & $\mathbf{. 8 5 1}$ & .635 \\
\hline Flavour \& Colour & & & &
\end{tabular}


Extraction Method : Principal Component Analysis

Rotation Method : Varimax with Kaiser Normalization

Source

: Primary Data

The above table exhibits the rotated factor loading for the twelve statements (variables) of product features influence the consumers on the buying decision of malted food drinks. It is clear from table that all the twelve statements have been extracted into four factors.

Table 6: Product features influence the consumers on the buying decision of Malted Food Drinks - Factor Wise Analysis

\begin{tabular}{|l|l|l|l|l|}
\hline Sl. No & Factors & $\begin{array}{l}\text { Eigen } \\
\text { Value }\end{array}$ & $\begin{array}{l}\text { Percentage } \\
\text { of Variance }\end{array}$ & $\begin{array}{l}\text { Cumulative } \\
\text { Percentage } \\
\text { Variance }\end{array}$ \\
\hline 1. & $\begin{array}{l}\text { Nutritious grains and } \\
\text { ingredients }\end{array}$ & 1.535 & 16.555 & 16.555 \\
\hline 2. & $\begin{array}{l}\text { Freshness and } \\
\text { nutrients content }\end{array}$ & 1.323 & 14.266 & 30.821 \\
\hline 3. & $\begin{array}{l}\text { Low cholesterol and } \\
\text { natural }\end{array}$ & 1.510 & 16.278 & 47.099 \\
\hline 4. & Flavour and Colour & 1.114 & 12.012 & 59.111 \\
\hline
\end{tabular}

Source: Computed Data

It is observed from table that four factors were extracted out of twelve variables. These factors accounts for 59.111 percentage variance in the data. Eigen value for the first factor is 1.535 which indicates that the factor contains very high information than other factors.

\section{Factor I (F1) - Nutritious grains and ingredients Factor}

Variables such as, 'Extraction from nutritious grains and nuts' (0.749), 'Digestive and absorbing elements' (0.651), 'Fragrance or Aroma' (0.577) and 'Ingredients' (0.531) had the highest significant positive loading and hence were included in the first factor. These variables were directly associated with the nutritious grains and ingredients. Hence, Factor I, was named as "Nutritious grains and ingredients Factor".

\section{Factor II (F2) - Freshness and nutrients content Factor}

In the second factor (F2) variables such as 'Taste' (0.685), 'Freshness' (0.675), 'Shelf life (Useable form still the last spoon)' (0.654), and 'Nutrients content (Minerals and Vitamins)' (0.636) were found to have the highest significant positive loading and hence they were grouped and included in Factor 2. Variables included in the second factor were closely associated with the freshness and nutrients content factor. So, the second factor was named as the 'Freshness and nutrients content' factor.

\section{Factor III (F3) - Low Cholesterol and Natural Factor}

Variables such as, 'Low/Nil fat or cholesterol' (0.768) and 'Natural one' (0.744) were found to have the highest significant positive loading and hence they were grouped and included in Factor 3. Hence, this factor III (F3) is called was named as the 'Low Cholesterol and Natural' factor. 
Factor IV (F4) - Flavour and Colour Factor

'Minimum or no preservatives/additives' (0.881) and 'Flavour \& Colour' (0.851) were the variables which were found to possess the highest significant positive loading and they had been included in the Factor IV(F4). These variables were related to flavour and colour. Hence, the Factor IV (F4) had been named as the 'Flavour and Colour' factor.

\section{Limitations of the Study}

1) This study is confined only to the selected five malted food item

2) The study is limited only to the study area that is Kanyakumari District. Therefore the findings of the study cannot be generalized.

3) Responses received from the respondents may not be fully reliable as some of the respondents might have filled up interview schedule reluctantly, with an intervention to conceal or without proper understanding.

\section{Findings}

1) It is observed that 44 per cent of the respondents are spending between $400-600$ for malted food in a month.

2) It is found that 28 per cent of the respondent's family are usually buying refill pack 200 grams and minimum of 3.7 per cent of the respondent's family are usually buy reusable jar 200 grams.

3) It is evident that 57.7 per cent of the respondent's children are regularly consuming malted food.

\section{Suggestions}

1) Since Indian consumers are actively becoming quality, health, and brand conscious as per the study, the marketers should take into consideration these factors seriously while designing or redesigning product mix and marketing mix.

2) As for as the product features are concerned, it is imperative on the part of marketers of malted food drinks to carefully consider inherent and important product features that are overwhelmingly preferred by consumers such as taste, nutrient content, fragrance/aroma, flavor etc. without compromising core values of their products.

3) It is highly important for marketers to design marketing mix strategies by taking into account demographic profile of consumers the presence of significant is not uniform with regard to brand preference.

\section{Conclusion}

Several studies carried out in India on consumer preference concluded that the characteristics of Indian consumers have undergone change since the inception of globalization and other related measures. The present study also reinforces the findings obtained through other studies carried out in this area. The study hs found a few strengths for the Indian malted food markets. It is anticipated that this study will form the basis for all future studies on this or relevant subjects. 


\section{References}

[1] Golden, S. A. R. (2016). Customers' Attitude Towards Online Shopping - An Analysis. International Journal of Business and Administration Research Review, 1(1), 453-455.

[2] Golden, S. A. R. (2016). SUBSCRIBERS'PREFERENCE TOWARDS MOBILE COMMUNICATION SERVICE-AN ANALYSIS. International Journal of Research Granthaalayah, 4(6), 1-13.

[3] Golden, S. A. R. (2017). Recent Research In Social Science \& Humanities.

[4] Pacific Business Review International Vol 5, issue 1. (July 2012).

[5] Regi, S. B., \& Golden, S. A. R. (2014). A DESCRIPTIVE STUDY ON THE ROLE OF CONSUMER PSYCHOLOGY AND BEHAVIOUR IN PRODUCT PURCHASING”. Indian Streams Research Journal, 3(12), 1-6.

[6] The Role of media on consumer Brand Choice - A case study of chocolate Industry Fazollah Kazemi, Malihe Esmeili. www.Ccsenet.or/ijbm, International Journal of Business Management, Vol 5 , No 9 Sep 2010.

[7] Trehan R and Singh H “A comparative studdey on Urban and Rural gementConsumer behavior", Indian Journal of Marketing Vol.33 (July), 2002.

[8] Varun T.C, M.G Kerntagi L.B.Kunnal, H. Basavaraja, K.V Ashalthat and M.T.Dodamani, Karnataka Journl of AAggriture Science 22 (4), 2009.

[9] Verma D.P.S and Savitha Hanspal: "Lifestyles and their Implications for service marketing", The Indian Journal of Commerce, Volum 52, No.2, April-June, 1999.

[10] Vinod Kumar Bishnoi and Bharti, Marketing to rural consumers - Understanding and tapping the rural market potential, 3,4 \& 5 April 2008. 